\title{
Characterization and molecular methods for detection of a novel spiroplasma pathogenic to Penaeus vannamei
}

\author{
Linda M. Nunan ${ }^{1, *}$, Carlos R. Pantoja1 ${ }^{1}$, Marcela Salazar $^{2}$, Fernando Aranguren $^{2}$, \\ Donald V. Lightner ${ }^{1}$
}

${ }^{1}$ Department of Veterinary Sciences and Microbiology, University of Arizona, Tucson, Arizona, 85721, USA

${ }^{2}$ CENIACUA, Carretera 8A \# 96-60, Bogota, Colombia

\begin{abstract}
Traditionally, Spiroplasma spp. have only been isolated from the surfaces of flowers and other plant parts, from the guts and hemolymph of various insects, and from vascular plant fluids (phloem sap) and insects that feed on these fluids. In this article, we report the first pathogenic spiroplasma to be discovered in shrimp and the results of its characterization through histological evaluation, in situ hybridization assays, transmission electron microscopy, 16S rRNA sequence homology, and injection infectivity studies. In addition, molecular methods are described that were developed for the detection of this microorganism, which was determined to be the causative disease agent in Colombian farm-raised Penaeus vannamei suffering from high mortalities. Using standard histological methods and in situ hybridization assays, it was confirmed that $P$. vannamei was infected with this pathogenic spiroplasma. Histological analysis revealed systemic inflammatory reactions in affected organs/tissues. In an attempt to identify the bacteria, frozen infected $P$. vannamei samples, from the initial epizootic, were used to sequence the 16S rRNA gene and develop molecular detection methods. The 16S rRNA gene was amplified by PCR and then sequenced. The sequence data were analyzed using the GenBank BLAST search and the results revealed a $98 \%$ homology with Spiroplasma citri, a pathogen of citrus trees. The 16S rRNA sequence data were evaluated for development of unique PCR primers to the putative spiroplasma. Using PCR primers developed for the spiralin gene of Spiroplasma spp., a digoxigenin-labeled probe was developed and tested. This probe was species-specific, with no positive reactions or cross-reactivity occurring with other bacterial samples tested in this format.
\end{abstract}

KEY WORDS: Spiroplasma $\cdot$ Penaeus vannamei $\cdot$ Shrimp

\section{INTRODUCTION}

In January 2002, severe mortalities of Penaeus vannamei occurred at approximately $120 \mathrm{~d}$ post-stocking (dps) in one pond at a Colombian shrimp farm, on the Caribbean coast. During the following growout period from May to June 2002, several ponds experienced high mortalities at $60 \mathrm{dps}$, with survival rates averaging $60 \%$. Individual pond survival rates ranged from 10 to $90 \%$. Another farm was affected in the next grow-out cycle in October at approximately 65 dps.
Clinical signs of diagnostic significance included expanded chromatophores and what the farmers referred to as 'standing shrimp syndrome', in which the floating, dead shrimp appeared to be balancing on their tails, looking at the sky. Histological examination of Davidson's-fixed moribund specimens revealed the presence of severe lesions suggestive of bacterial infection, which later were determined to be due to a novel Spiroplasma sp., pathogenic to Penaeus vannamei.

The genus Spiroplasma (class Mollicutes) has been previously isolated from the guts and hemolymph of various insects and ticks (Tully et al. 1982, Williamson 
et al. 1989, 1998, Tully \& Whitcomb 1990). These microorganisms have also been isolated from the surface of plants, plant vascular fluids and the insects that feed on these fluids (Clark et al. 1987, Hackett \& Clark 1989). Species of the genus Spiroplasma are wall-less eubacteria with an internal, membrane-bound cytoskeleton. Spiroplasmas are motile, even though they lack flagella, and are characterized by their helical morphology (Foissac et al. 1996, 1997, Trachtenberg 1998) Some, but not all, species of spiroplasma are naturally pathogenic to plants and insects (Tully et al. 1977, Hackett \& Lynn 1985, Barros et al. 2001).

This study presents 2 molecular methods, in situ hybridization and PCR assays, developed for the detection of the spiroplasma isolated from Penaeus vannamei. In addition, infectivity data are presented that confirm the pathogenicity of this novel microorganism.

\section{MATERIALS AND METHODS}

Identification of pathogen. Samples of Penaeus vannamei from ponds in Colombia suffering from mortalities were either preserved in Davidson's AFA fixative (Bell \& Lightner 1988) for histopathological examination and in situ hybridization assays or frozen. Histological specimens were embedded in ParaPlast Plus paraffin (Fisher Scientific), sectioned at $4 \mu \mathrm{m}$ thickness, mounted onto microscope slides, deparaffinized and stained with Mayer-Bennett's hematoxylin/eosin (H\&E) phloxin (Lightner 1996). Examination of histological specimens was performed using standard light microscopy. Histological terms used in this study follow Bell \& Lightner (1988) and shrimp taxonomy is in accordance with Holthuis (1980). Upon arrival at the laboratory, frozen samples were maintained at $-80^{\circ} \mathrm{C}$ for use in infectivity studies and PCR amplification of the 16S rRNA gene.

Infectivity in Peneaus vannamei and development of molecular detection methods. Specific pathogenfree (SPF) juvenile Penaeus vannamei, $5 \mathrm{~g}$ average weight, were injected $(0.1 \mathrm{ml})$ into the third abdominal segment with a tissue homogenate prepared from frozen, naturally infected shrimp that originated from Colombia. Injected shrimp were monitored daily for moribund specimens and mortalities. Hemolymph was first drawn from moribund shrimp to be used as the starting material for culturing the microorganism and then the shrimp were either preserved in Davidson's fixative for histological evaluation and in situ hybridization assays, or frozen for PCR analysis. Mortalities were recorded daily.

DNA extraction and amplification of the 16S rRNA gene. Fifty mg of tissue was sampled from the cephalothoracic region of frozen Penaeus vannamei that origi- nated from the infectivity study. Attempts were made to include ventral nerve cord tissue in this sample, as previous histological analysis performed at our laboratory had indicated this to be one of the most severely affected organs/tissues. Total DNA was extracted from sampled tissue using the 'High Pure PCR Template Preparation Kit' (Roche Diagnostics), following the manufacturer's protocol. One $\mu \mathrm{l}$ of the extracted DNA was used as the PCR template and amplified with 16S rRNA 'universal' primers according to a previously published protocol for amplification of the 16S rRNA gene (Nunan et al. 2003a). The amplified PCR product, approximately $1500 \mathrm{bp}$ in length, was run on a $0.8 \%$ agarose gel in TBE buffer (tris-borate-EDTA) with ethidium bromide $\left(0.5 \mu \mathrm{g} \mathrm{ml}^{-1}\right)$ incorporated into the gel (Maniatis et al. 1982).

Sequencing and sequence comparison of the $16 \mathrm{~S}$ rRNA gene PCR fragment. The PCR reaction mixture containing the amplified product was eluted using the QIAquick PCR Purification Kit (Qiagen), following the manufacturer's protocol. The eluted DNA concentration was determined at $260 \mathrm{~nm}$ using a BioPhotometer (Eppendorf). The approximately $1500 \mathrm{bp}$-long product was sequenced at the University of Arizona Research Laboratory DNA Sequencing Facility. The forward and reverse sequences were aligned and compared to known 16S rRNA sequences from GenBank.

Culturing the microorganism. Based on the homologies determined by the GenBank BLAST search, the unknown pathogenic bacteria was found to be closely related to the genus Spiroplasma and an attempt was made to culture the microorganism based on this tentative classification. Hemolymph, collected from moribund Penaeus vannamei from the infectivity study, was filtered through a $0.45 \mu \mathrm{m}$ Acrodisc syringe filter (Pall Corporation) and the filtrate was inoculated into M1D media (Jones et al. 1977, Whitcomb et al. 1982), supplemented with $2 \% \mathrm{NaCl}$. The inoculated media was incubated at $30^{\circ} \mathrm{C}$. Due to the diminutive size of the spiroplasmas, which cannot be visualized by standard light microscopy, phenol red was added to the M1D media and used to indirectly assess their growth. Phenol red turns from red to orange to yellow as the bacterial population increases in size.

Electron microscopy. Sample preparation: Two ml aliquots of bacterial suspension were collected from M1D culture flasks that had acquired a translucent orange discoloration. Portions of $1 \mathrm{ml}$ of bacterial suspension were dispensed into sterile $1.5 \mathrm{ml}$ microcentrifuge tubes and the bacteria was pelleted in a refrigerated microcentrifuge at $3000 \times g$ for $1 \mathrm{~min}$. The supernatant fluids were transferred into clean microcentrifuge tubes and the pellets were resuspended in $50 \mu \mathrm{l}$ of the same supernatant fluid. 
Transmission electron microscopy: Drops of resuspended bacterial pellets were placed on the surface of a clean piece of parafilm and clean Formvar/carboncoated copper grids were floated on the surface of each drop for $3 \mathrm{~min}$. The grids were then immediately transferred onto drops of $2 \%$ aqueous phosphotungstic acid (PTA), pH 7.0, and stained for 3 min. Excess stain was blotted away with a piece of filter paper and the grids were air-dried for several hours before examination in a CM12 Philips transmission electron microscope operated at $80 \mathrm{kV}$.

Scanning electron microscopy: A drop of resuspended bacterial pellets was placed on a poly-L-lysine coated glass coverslip and allowed to sit at room temperature for $5 \mathrm{~min}$. Following a rinse with $\mathrm{PBS}$, the sample was fixed in $3 \%$ glutaraldehyde in $0.1 \mathrm{M}$ cacodylate buffer for $1 \mathrm{~h}$ at $4^{\circ} \mathrm{C}$. The sample was rinsed in $0.1 \mathrm{M}$ cacodylate buffer and post-fixed in $1 \%$ osmium tetroxide in $0.1 \mathrm{M}$ cacodylate buffer for $1 \mathrm{~h}$ at room temperature. The sample was then rinsed in the above buffer, dehydrated through a graded series of ethanols, and dried using hexamethyldisilazane. The coverslip was mounted on a stub and sputter-coated with $15 \mathrm{~nm}$ gold. The sample was examined on a Philips XL30 scanning electron microscope.

Selection of spiroplasma-specific PCR primers. Two oligtonucleotide primers (CSF: 5' TAG CCG AAC TGA GAG GTT GA 3' and CSR 5' GAT AAC GCT TGC CAC CTA TG $3^{\prime}$ ) that amplify a $269 \mathrm{bp}$ fragment were selected from a variable region of the 16S rRNA gene sequence. To determine the variable regions of the gene, deposited Spiroplasma spp. sequence data, available from GenBank, were evaluated and compared to the sequence from the shrimp spiroplasma. The computer software program Primer Designer 4 (Scientific and Education Software) was used to design the primers. The primers were synthesized by Sigma Genosys.

PCR amplification of spiroplasma-infected tissue and media culture. DNA, used for the PCR templates, was extracted (High Pure PCR Template Preparation Kit) from infected tissues from the original frozen samples from Colombia, from frozen samples from the infectivity study, and from the M1D media-grown culture. The optimized PCR reaction mixture contained $10 \mathrm{mM}$ PCR buffer (Tris- $\mathrm{HCl}, 50 \mathrm{mM} \mathrm{KCl}, \mathrm{pH}$ 8.3), $1 \mathrm{mM}$ dNTP each, $20 \mathrm{pmol}$ of each of the 2 primers (CSF and CSR), $2.5 \mathrm{U}$ AmpliTaq gold polymerase, $2 \mathrm{mM}$ $\mathrm{MgCl}_{2}$ (Roche Molecular Systems), 100 to $300 \mathrm{ng}$ DNA template and sterile $\mathrm{H}_{2} \mathrm{O}$ in a $50 \mu \mathrm{l}$ volume. The thermal cycling program comprised an initial denaturing step for $2 \mathrm{~min}$ at $95^{\circ} \mathrm{C}$, followed by 35 cycles of annealing for $30 \mathrm{~s}$ at $60^{\circ} \mathrm{C}$, extension for $30 \mathrm{~s}$ at $72^{\circ} \mathrm{C}$, denaturation for $30 \mathrm{~s}$ at $95^{\circ} \mathrm{C}$, ending with 1 cycle at $60^{\circ} \mathrm{C}$ for $1 \mathrm{~min}$ and $72^{\circ} \mathrm{C}$ for $2 \mathrm{~min}$. The amplified PCR products were held at $4^{\circ} \mathrm{C}$ after completion of the run and until processing.
In situ hybridization assay development. Spiroplasmas possess a unique membrane protein named spiralin (Foissac et al. 1997). For the development of in situ hybridization assays, the spiralin gene of the spiroplasma organism was targeted. Two published primers and PCR protocol (Foissac et al. 1997) that have been used to amplify spiralin genes from Spiroplasma phoeniceum and $S$. kunkelii were tested on the extracted DNA used in the PCR amplifications. The amplicon generated using the spiralin primers was $481 \mathrm{bp}$. Extracted DNA from media-grown bacteria was the DNA template labeled with digoxigenin (DIG)-11 dUTP by PCR using the spiralin-specific primers, following the manufacturer's instructions (Genius I Kit, Roche Diagnostics). This DIG-labeled probe was tested by in situ hybridization following the protocol of Poulos et al. (1994). Overnight hybridization with the DIGlabeled probe was done in a humid chamber at $37^{\circ} \mathrm{C}$.

Cloning of spiroplasma and spiralin PCR-amplified fragments. The 269 and 481 bp PCR-amplified products were eluted from the PCR reaction mixtures using the QIAquick PCR Purification Kit. The concentrations of eluted DNA were calculated using a BioPhotometer. The fragments were ligated with T4 DNA ligase into the EcoRV site of the pGEM-T Easy Vector System II (Promega Corporation) and transformed into JM109 competent cells. Following transformation, the bacteria were spread onto LB-amp plates that were pretreated with Xgal (5-bromo-4-chloro-3-indolyl- $\beta$-Dgalactoside) and IPTG (isopropyl-1-thio- $\beta$-D-galactoside) (Maniatis et al. 1982). Incubation occurred overnight at $37^{\circ} \mathrm{C}$. White colonies were selected and grown in $5 \mathrm{ml}$ LB-amp broth at $37^{\circ} \mathrm{C}$ overnight, with shaking. The following day, cultures were tested directly by pipetting $1 \mu \mathrm{l}$ of the broth into the PCR reaction mixtures containing the primers specific for the spiroplasma developed from either the 16S rRNA or the spiralin gene and amplified using the optimized cycling programs. The cloned DNA was either used as the positive control for the PCR assays or for the PCR template in the DIG-labeling protocol.

Dilution infectivity studies. M1D media-grown culture, second passage, was used as the inoculum for the dilution infectivity studies. One $\mathrm{ml}$ of the $5 \mathrm{~d}$, orangecolored culture was centrifuged at $3000 \times g$ to pellet the bacteria. The pellet was resuspended in $1 \mathrm{ml} 2 \%$ sterile saline. Serial dilutions were made using $2 \%$ sterile saline to 1:1000 000. The inocula tested in the infectivity studies were undiluted, 1:100. 1:10000 and 1:100 000. SPF Penaeus vannamei, weighing approximately $1 \mathrm{~g}$, were obtained from the Oceanic Institute in Hawaii (Wyban et al. 1992, Pruder et al. 1995). Four groups of 10 SPF shrimp were each injected into the third abdominal segment with $50 \mu$ l of a different dilution/inoculum, using a sterile $1 \mathrm{ml}$ syringe fitted with a 
26 gauge needle. The negative control shrimp were injected with only $2 \%$ sterile saline. The 5 experimental $90 \mathrm{l}$ glass aquaria were maintained at a constant $30^{\circ} \mathrm{C}$ water temperature using submersible water heaters. Each aquarium was fitted with a biological filter and maintained as previously described by Nunan et al. (2003b). Samples of moribund shrimp were preserved in Davidson's fixative to confirm disease status by histological examination and in situ hybridization assays. A negative control shrimp was sampled at the end of the experiment to confirm the initial SPF status of the population.

\section{RESULTS}

\section{H\&E histopathology}

Histological examination of Davidson's-fixed moribund Penaeus vannamei originating from outbreaks in Colombia revealed the presence of lesions highly suggestive of systemic bacterial infection. Affected shrimp displayed multifocal, moderate to severe, systemic inflammatory reactions in the form of hemocytic congestion, coagulation of hemocytes into loose clots, hemocytic nodule formation, phagocytosis (sometimes accompanied by melanization) and fibrosis. Among the affected organs/tissues were ventral nerve cord (including nerve tracts, ganglia and neurilema), skeletal muscle, heart, antennal gland, lymphoid organ, fibrous connective tissue within the hepatopancreas, spongy connective tissue around the stomach, gill filaments, and subcutis of carapace and body appendages.

Lesion development seemed to progress as follows: (1) presence of necrotic cells exhibiting pyknotic nuclei, (2) migration and congregation of phagocytic cells within necrotic areas, (3) phagocytosis of necrotic cells and debris and/or formation of hemocytic nodules, (4) melanization of hemocytic nodules, and (5) fibrocytic inflammation (Fig. 1). In many instances, necrotic cells displayed cytoplasmic vacuoles of variable size, which appeared to contain a faintly basophilic material (Fig. 1).

\section{Sequence comparisons}

The BLAST search of the sequenced 16S rRNA gene revealed a $98 \%$ match in the homology block with the organism Spiroplasma citri (Saglio et al. 1973, Weisburg et al. 1989; GenBank Accession Nos. M23942 and X63781). A $97 \%$ homology block match was elucidated with $S$. poulsonii (Weisburg et al. 1989, Williamson et al. 1999; GenBank Accession Nos. M24483 and AJ579919). The homology of the sequences was a preliminary indication that the bacteria isolated from the infected Penaeus vannamei was closely related to Spiroplasma spp.

\section{Culturing the organism}

Hemolymph samples were drawn from moribund shrimp from the initial infectivity study, whereby frozen infected carcasses, originating from Colombia, were used to prepare the inoculum to be injected. On Day 9 post injection, $700 \mu \mathrm{l}$ of hemolymph was added to $1 \mathrm{ml}$ of M1D media (supplemented with $2 \% \mathrm{NaCl}$ ), filtered $(0.45 \mu \mathrm{m})$, and added to $4 \mathrm{ml} \mathrm{M} 1 \mathrm{D}$ media. The culture was incubated at $30^{\circ} \mathrm{C}$, and $6 \mathrm{~d}$ following inoculation of the media, the phenol red color indicator had changed from red to orange. One $\mathrm{ml}$ of the culture was transferred into $4 \mathrm{ml}$ of fresh media for the first passage. Additional $1 \mathrm{ml}$ aliquots were frozen at $-80^{\circ} \mathrm{C}$ for future reconstitution. Transmission electron microscopy (TEM) was used to determine if the spiroplasma had grown in the inoculated media. The culture was passaged 10 times, with TEM analysis confirming the integrity of the spiroplasma cells prior to freezing or lyophilizing. Both frozen and lyophilized cultures were reconstituted into M1D media to confirm viability.

\section{Transmission electron microscopy}

Transmission and scanning electron microscopy (TEM and SEM) analysis of bacteria confirmed their pleomorphic nature. Filaments of variable length and width, many of them clearly helical, were observed (Fig. 2). Many of the filamentous forms also displayed vesicular blebs very similar to those previously described from Spiroplasma citri (Razin et al. 1973).

\section{PCR amplification with specific primers derived from the 16S rRNA gene sequence}

DNA extracted from the media-grown spiroplasma culture was amplified by PCR using both the 'universal' bacterial primers and the primers specific to the spiroplasma. To further test the specificity of these primers, DNA for PCR templates was extracted from several common, culturable, marine Vibrio species originating from Ecuador, Mexico, Madagascar and the USA (specifically, Texas, Arizona, Hawaii and Louisiana). Additional DNA from media-cultured bacteria that were tested by the PCR format included Aeromonas sp. and Pseudomonas sp. (Louisiana). DNA that was extracted from shrimp tissues infected with 

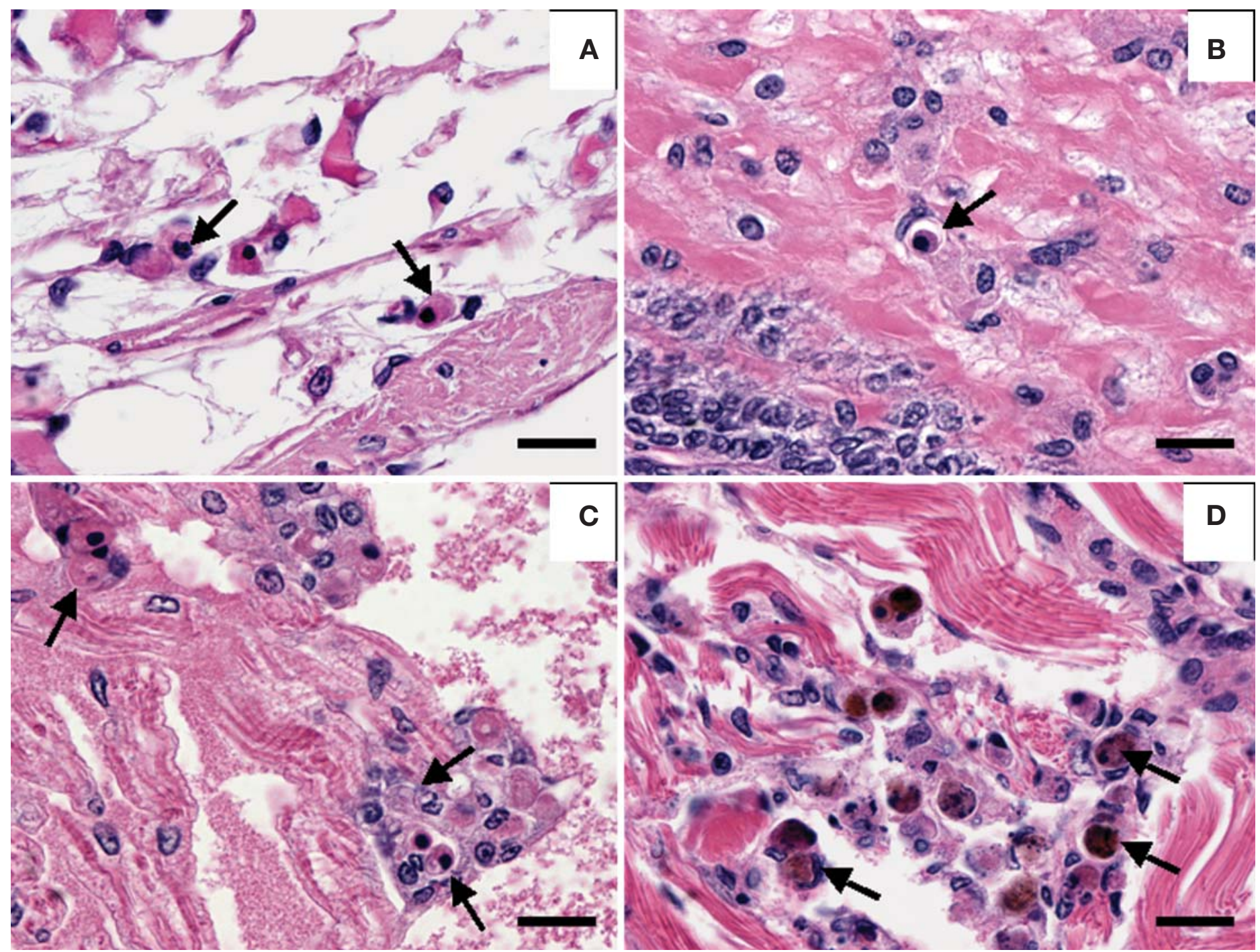

Fig. 1. Penaeus vannamei. Histopathological findings from clinical samples originated from shrimp farms with spiroplasma outbreaks. (A) Necrotic spongy connective tissue cells, displaying pyknotic nucleus (arrows). (B) Necrotic spongy connective tissue cell in process of being engulfed by a phagocyte (arrow). (C) Agglomerated phagocytic cells, either surrounding or ingesting necrotic cells between heart-muscle fibers, arrows point to examples of necrotic cells with cytoplasmic vacuoles of variable size whose contents appear to be faintly basophilic. (D) Phagocytosis of necrotic cells and formation of hemocytic nodules between skeletal muscle fibers; arrows point to examples of melanized hemocytic nodules. Hematoxylin/eosin-phloxin stain. Scale bars $=10 \mu \mathrm{m}$

the shrimp pathogen, a rickettsia-like organism causing necrotizing hepatopancreatitis (NHP) (Frelier et al. 1992, Loy et al. 1996), was also tested in this format to confirm specificity of the PCR primers. When the 'universal' bacterial primer set was used, PCR amplification of approximately $1500 \mathrm{bp}$ amplicons occurred in all samples tested, with the exception of the negative control. When the spiroplasma-specific primer pair was used in the optimized PCR assay, the DNA extracted from the cultured spiroplasma was the only sample to generate an amplicon of the expected size (269 bp) (Fig. 3).

\section{In situ hybridization assays using the digoxigenin (DIG)-labeled spiralin clone}

The specificity of the DIG-labeled spiralin probe was validated by testing several bacteria-infected Davidson's-preserved samples by the in situ hybridization format. These samples included a rickettsia-like bacterium (RLB) originating from Madagascar (Nunan et al. 2003a), the causative agent for NHP (Frelier et al. 1992), a rickettsial organism from Penaeus monodon cultured in Malaysia (Anderson et al. 1987), and Vibrio sp. (University of Arizona; origin Mexico). A positive hybridization 


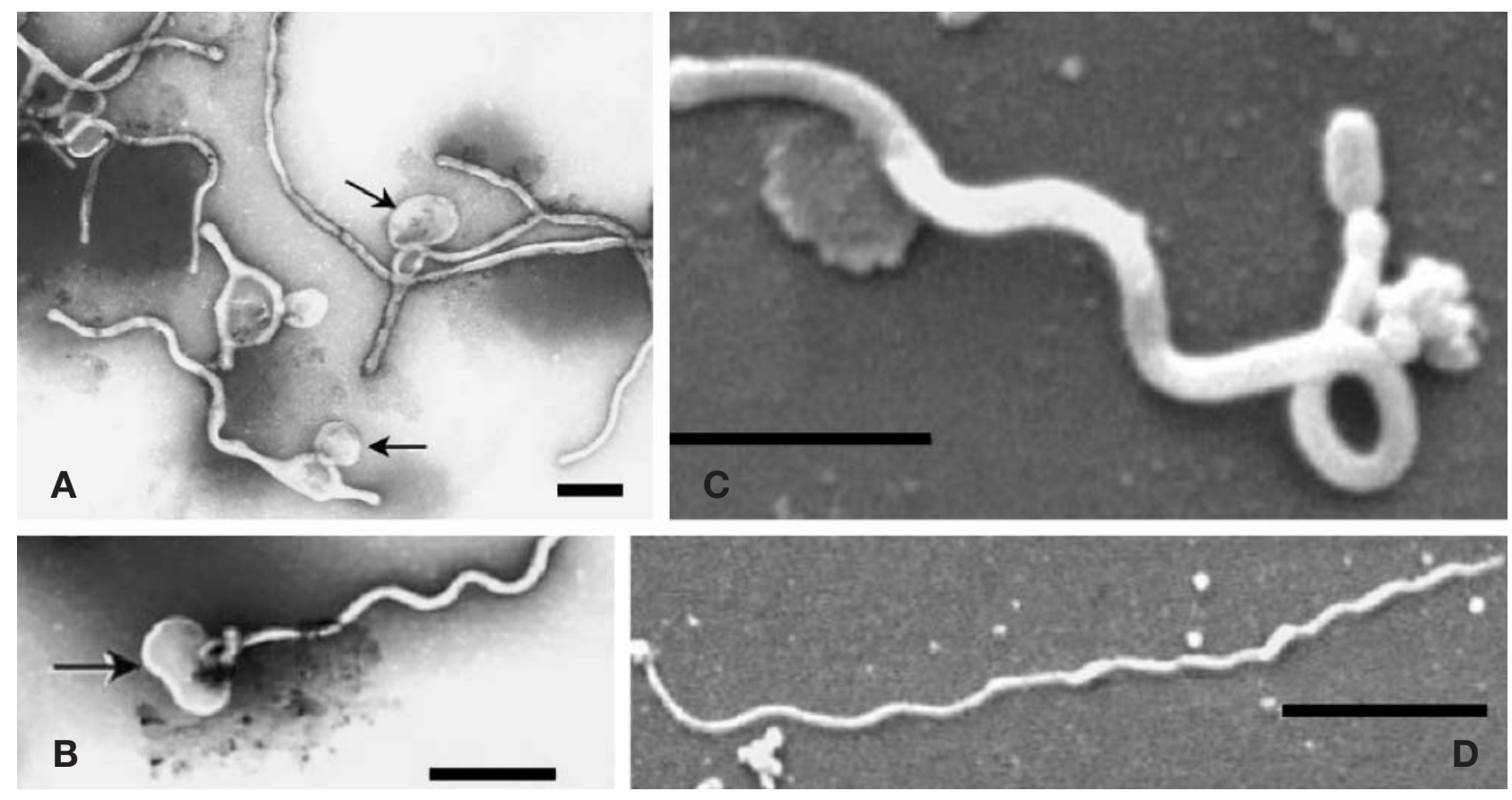

Fig. 2. Transmission (TEM) and scanning (SEM) electron microscopy of bacteria from inoculated media. (A,B) TEM of negatively stained bacterial preparations showing their filamentous morphology as well as presence of vesicular blebs (arrows); (C,D) SEM microphotographs showing examples of helical forms. Scale bars: $A=0.5 \mu \mathrm{m} ; \mathrm{B}=1.0 \mu \mathrm{m} ; \mathrm{C}, \mathrm{D}=2.0 \mu \mathrm{m}$

signal, visualized as a blue/black precipitate associated with the cellular changes caused by the spiroplasma infection, was seen in both naturally and experimentally infected specimens. The DIG-labeled probe failed to hybridize with the SPF sample and with any of the shrimp infected with other types of bacteria.

A positive reaction to the DIG-labeled spiralin probe (i.e. deposition of a dark blue/black precipitate) was observed within the following tissues/organs: ventral nerve cord (including nerve tracts, ganglia and neurilema), skeletal muscle, heart, antennal gland, lymphoid organ, fibrous connective tissue within the hepatopancreas, spongy connective tissue around the stomach, gill filaments, and subcutis of carapace and body appendages. The positive reaction to the probe could also be observed within the cytoplasm of cells in the affected organs/tissues, and also diffusely near necrotic foci (Fig. 4).
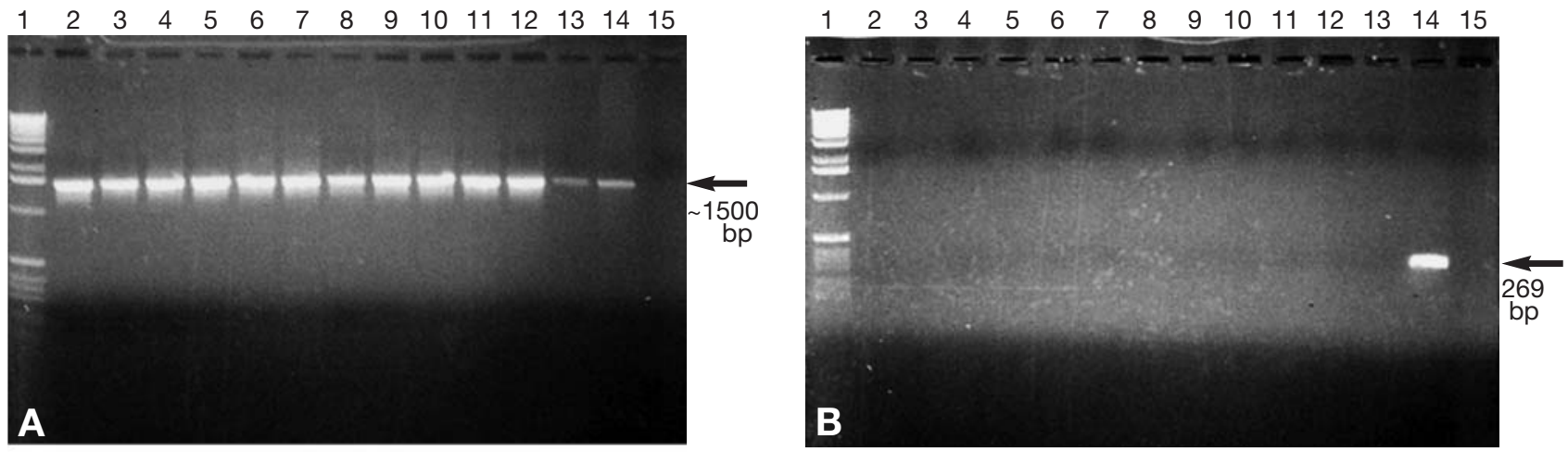

Fig. 3. Electrophoretic patterns in a 1\% agarose gel using (A) bacterial 16S rRNA primers and (B) spiroplasma-specific primers. Geographical origins of bacterial isolates are given in parentheses: Lane $1=1 \mathrm{~kb}$ marker; Lane $2=$ Vibrio parahaemolyticus (Ecuador); Lane $3=V$. parahaemolyticus (Texas, USA); Lane $4=$ Vibrio sp. (Mexico); Lane $5=$ Vibrio sp. (Madagascar); Lane $6=$ $V$. parahaemolyticus (Arizona, USA); Lane $7=$ Vibrio sp. (Texas, USA); Lane $8=V$. vulnificus (Hawaii, USA); Lane $9=V$. alginolyticus (Madagascar); Lane $10=$ Aeromonas sp. (Louisiana, USA); Lane $11=$ V. fluvialis (Arizona, USA); Lane 12 = Pseudomonas sp. (Louisiana, USA); Lane 13 = necrotizing hepatopancreatitis (Texas, USA); Lane $14=$ shrimp spiroplasma, positive control (Colombia); Lane 15 = negative specific pathogen-free control (Hawaii, USA) 


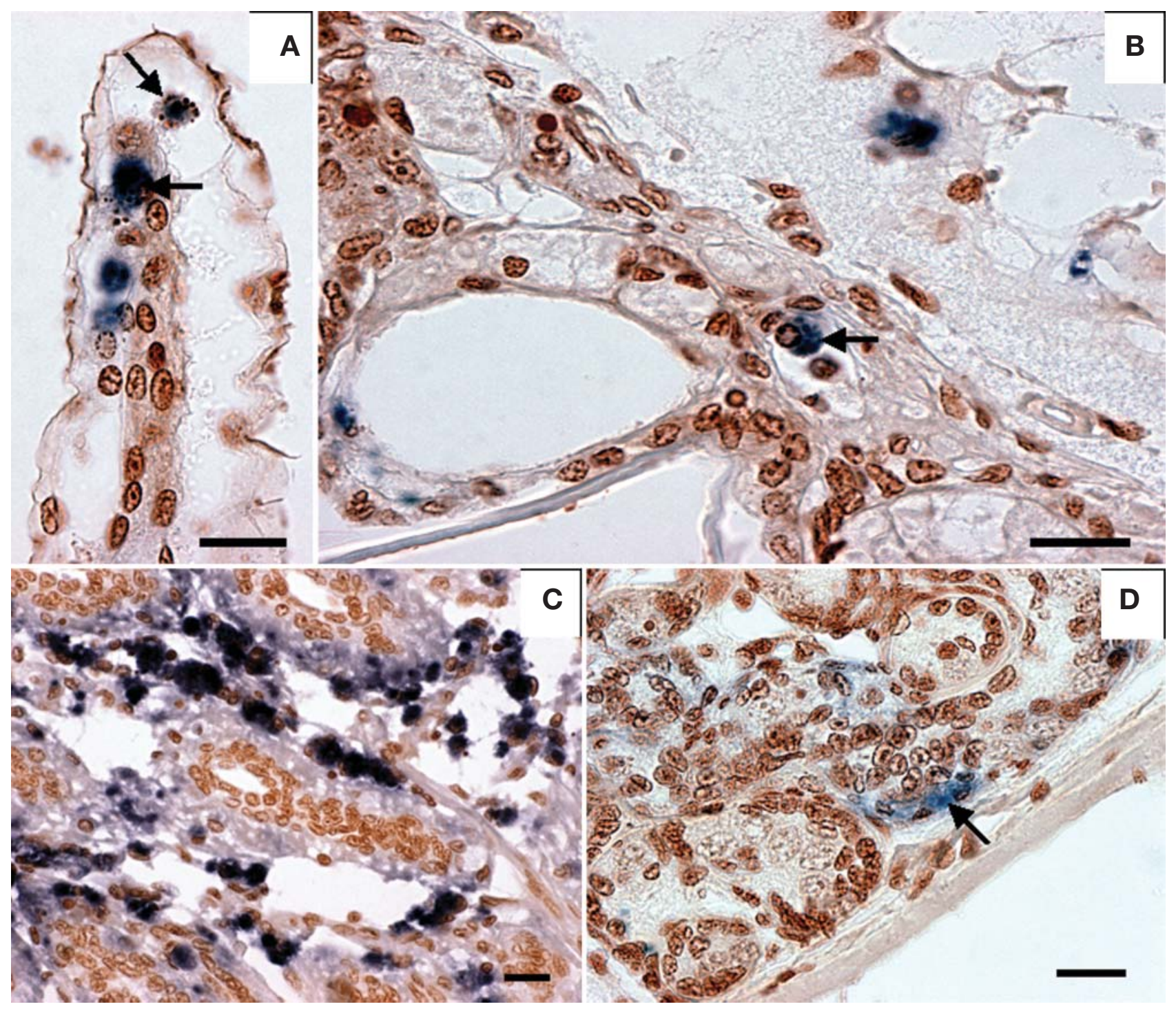

Fig. 4. Examples of positive reaction to spiralin DIG-labeled gene probe after in situ hybridization assay (ISH). (A) Positive ISH reaction, as indicated by deposition of a dark-blue or black precipitate within gill filament; arrows point to examples of a diffuse positive reaction amongst cell debris. (B) Positive ISH reaction within cytoplasmic vesicles of cell undergoing necrosis (arrow). (C) Intense positive ISH reaction within the lymphoid organ; strongest reaction is observed within fibrous connective tissue cells, less intense reaction within cytoplasm of sheath cells. (D) Positive ISH reaction within cytoplasm of spermatogonial cells (arrow), highly suggestive of possibility for vertical transmission. Bismark Brown counterstain. Scale bars $=20 \mu \mathrm{m}$

\section{Dilution infectivity studies}

Mortalities of the experimentally infected (4 groups of 10 each) SPF Penaeus vannamei began with 6 mortalities $2 \mathrm{~d}$ post injection (d.p.i.) using the undiluted inoculum, and continued until the 4 remaining shrimp died at 3 d.p.i. The 1:100 inoculum caused the onset of mortalities at 4 d.p.i., when 3 shrimp died; 5 additional mortalities occurred at 5 d.p.i., with the final 2 shrimp succumbing to the bacterial infection at 6 d.p.i. The next dilution tested, 1:10000, caused mortalities to begin at 7 d.p.i., when 5 shrimp died; at 8 d.p.i., 4 addi- tional shrimp died, and at 10 d.p.i. the last surviving shrimp died. The last dilution examined (1:1000 000) caused mortalities to begin at 7 d.p.i., when 1 mortality occurred; at 8 d.p.i., an additional single mortality was observed. The remaining shrimp died at 14 d.p.i. (2 mortalities), 15 d.p.i. (3 mortalities), 17 d.p.i. (2 mortalities), followed by the final shrimp dying at 18 d.p.i. (Fig. 5). No mortalities of the SPF negative control group that had been injected with sterile $2 \%$ saline occurred during the $18 \mathrm{~d}$ experiment. Moribund samples from the 4 experimental tanks were preserved in Davidson's fixative for histology and in situ gene-probe 

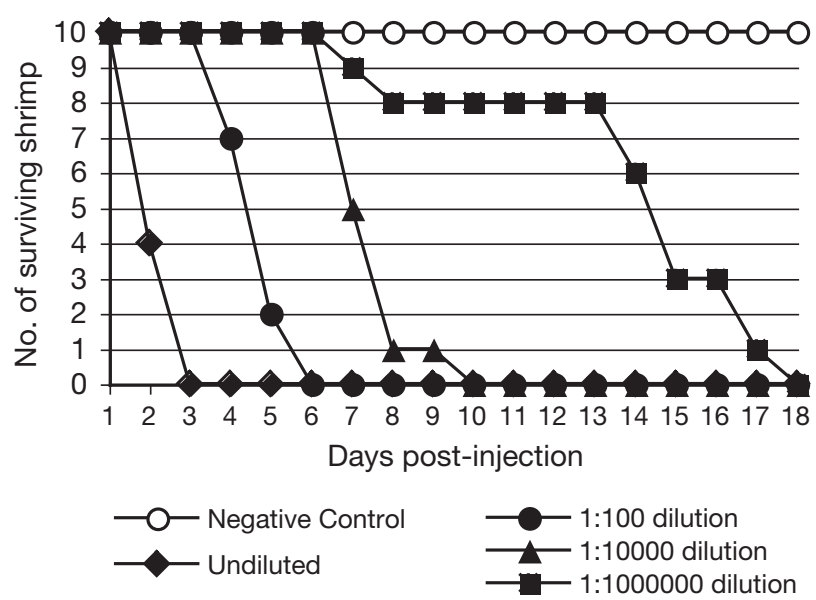

Fig. 5. Dilution effects on mortalities. Daily percentage survival of specific pathogen-free Penaeus vannamei injected with 4 different dilutions prepared from the media-cultured spiroplasma

analysis (Fig. 4). All the experimentally infected specimens examined displayed moderate to severe spiroplasma infection. Histological evaluation and in situ hybridization assays confirmed the spiroplasma disease status of the experimentally infected shrimp. A survivor from the negative control tank was also sampled. This sample served to confirm the initial SPF status of the population tested and also acted as the negative control for the in situ hybridization assays.

\section{DISCUSSION}

The severity and type of lesions found during the histological analysis of clinical specimens of Penaeus vannamei that originated from affected Colombian farms were, from the beginning, suggestive of severe bacterial infection. The inflammatory response observed in these shrimp was highly reminiscent of that which appears as a result of systemic Vibrio sp. infections (i.e. seagull syndrome; Mohney et al. 1994), the difference being that no individual bacterial rods or bacterial microcolonies were evident in the vicinity of necrotic and/or inflammatory lesions, as is typically observed in systemic vibriosis. Possibly, this disease may have been previously misdiagnosed or escaped detection due to lack of adequate diagnostic methods.

The development of molecular-based assays for this putative spiroplasma organism has proven useful in differentiating it from other systemic bacterial diseases of shrimp. The development of the PCR assay was contingent upon the DNA sequence from the 16S rRNA gene. The spiralin gene may have been another option for PCR primer design, but unfortunately when the spiralin gene sequence was analyzed, no optimal pri- mers within the $481 \mathrm{bp}$ sequence were found; hence the 16S rRNA gene sequence had to be used for selection of PCR primers. Once the PCR protocol was optimized for the use of these primers, the specificity was demonstrated by testing extracted DNA from other marine bacteria commonly pathogenic to shrimp, including the causative bacterium of NHP, Pseudomonas sp., Aeromonas sp. and several Vibrio spp. No amplification occurred in any of the bacterial isolates tested, with the exception of the spiroplasma, thus demonstrating the specificity of the assay.

For the development of the DIG-labeled probe, the spiralin gene of the spiroplasma was targeted in an attempt to ensure the specificity of the in situ hybridization assay. Traditionally, Spiroplasma spp. have not been recognized as shrimp pathogens or even as commensals; thus the risk of a spiralin DIG-labeled probe cross-reacting with similar Spiroplasma spp. genomes in the shrimp, although possible, was minimal. The development of the probe was based on the PCR primers and protocol developed by Foissac et al. (1997), which amplify a $1 \mathrm{~kb}$ fragment of the spiralin genes of $S$. phoeniceum and $S$. kunkelii. Using the PCR primers designed by Foissac et al. (1997) and DNA extracted from the M1D media-cultured bacteria from this study as a template, a $481 \mathrm{bp}$ product was generated. Even though this PCR amplicon was less than half the expected size, the fragment was DIG-labeled and tested by the in situ hybridization assay format. Paraffin sections from both naturally and experimentally infected shrimp were successfully subjected to this assay. A positive reaction to the probe was observed within all of those tissues/organs where conventional H\&E analysis had previously suggested the presence of the causative agent. The DIG-labeled probe did not produce a reaction against other shrimp specimens infected with various pathogens (i.e. 2 RLB isolates or marine Vibrio spp.), confirming the specificity.

The infectivity experiments served 2 purposes in this study. The first goal was to confirm that this spiroplasma was indeed the cause of the lesions and mortalities observed in clinical specimens, and the second to test the pathogenicity of the microorganism. However, since purified bacteria are essential for these experiments, the spiroplasma had to be first isolated. Being a novel pathogen in shrimp, no specific information was available on how to isolate and culture a spiroplasma of marine origin. Our research proved useful in determining that the same M1D media formulated for Spiroplasma spp. of insect and plant origin could be used for isolation and culture with minimal modification (i.e. supplementation with $2 \% \mathrm{NaCl}$ ). Once the microorganism was successfully grown in vitro, we proceeded with the demonstration of the cause of the disease and with the pathogenicity studies. The results 
of the dilution infectivity experiment show that this new spiroplasma is highly pathogenic to Penaeus vannamei. Even at the highest dilution of the microorganism $(1: 1000000)$, a $100 \%$ mortality was reached at 18 d.p.i.; $100 \%$ was also observed in the tanks with shrimp inoculated with more concentrated dilutions, but took less time. In the negative control tank, in which the shrimp were injected with sterile saline only, there was $100 \%$ survival of the experimental shrimp. The confirmation that the shrimp from the dilution infectivity study had actually died of spiroplasma infection was accomplished by conventional H\&E histology coupled to in situ hybridization with the DIG-labeled spiralin probe. The lesions presented by the shrimp in the infectivity study demonstrated that this spiroplasma was indeed the causative agent of the lesions observed in diseased shrimp originating from the outbreaks in Colombia.

From a shrimp-culture perspective, stocking densities and good pond management, which includes a long drying period between growth cycles, have reduced the negative effect of these disease outbreaks at shrimp farms in Colombia and have helped increase the yields in ponds where this microorganism has been detected by PCR testing. Until present, this microorganism has not been identified in ponds with salinities above 20 ppt. Mortalities usually follow stress situations brought on by low oxygen levels.

Based on our results, this bacteria may be tentatively characterized as a spiroplasma. Its size and morphology, as revealed by TEM and SEM, and its 16S rRNA gene sequence strongly support this contention.

Further studies are needed to properly classify and name this microorganism. Beyond culturing the bacteria, morphological characterization and genome analysis, additional serological and biochemical tests need to be conducted. Additional studies will have to include determination of sterol requirements for growth, and testing biochemical and biological properties, including glucose fermentation and hydrolysis of arginine and urea (Aluotto et al. 1970). Serological tests, using antisera produced in rabbits, are also a necessary criteria for determining metabolism inhibition and for deformation tests (Williamson et al. 1979). Once these additional tests have been performed, this novel spiroplasma could be officially recognized as part of a genus that so far includes only representatives found associated with plants and insects.

Acknowledgements. Funding for this research was provided by a grant from the USMSFP, USDA, CSREES, Grant No. 2002-38808-01345. The authors would like to thank Bonnie Poulos, Brenda White-Noble, Leone Mohney and Rita Redman for their input and/or assistance in conducting these experiments. We are also grateful to Peggy McCuskey, from the Imaging Facility Division of Biotechnology of the University of Arizona, for her technical support. In addition, Dr. Gail Gasparich and Dr. Robert Whitcomb were invaluable advisors concerning the Spiroplasma spp.

\section{LITERATURE CITED}

Aluotto BB, Wittler RG, Williams CO, Faber JF (1970) Standardized bacteriologic techniques for characterization of Mycoplasma species. Int J Syst Bacteriol 20:35-58

Anderson I, Shariff M, Nash G, Nash M (1987) Mortalities of juvenile shrimp Penaeus monodon, associated with Penaeus monodon baculovirus, cytoplasmic reo-like virus, and rickettsial and bacterial infections from Malaysian brackishwater ponds. Asian Fish Sci 1:47-64

Barros TSL, Davis RE, Resende RO (2001) Design of polymerase chain reaction for specific detection of corn stunt spiroplasma. Plant Dis 85:475-480

Bell TA, Lightner DV (1988) A handbook of normal penaeid shrimp histology. World Aquaculture Society, Baton Rouge, LA

Clark TB, Henegar RB, Rosen L, Hackett KJ and 5 others (1987) New spiroplasmas from insects and flowers: isolation, ecology, and host association. Isr J Med Sci 23: $687-690$

Foissac X, Saillard C, Gandar J, Zreik L, Bove J (1996) Spiralin polymorphism in strains of Spiroplasma citri is not due to differences in posttranslational palmitoylation. J Bacteriol 178:2934-2940

Foissac X, Bove J, Saillard C (1997) Sequence analysis of Spiroplasma phoeniceum and Spiroplasma kunkelii spiralin genes and comparison with other spiralin genes. Curr Microbiol 35:240-243

Frelier PF, Loy JK, Kruppenbauch B (1992) Transmission of necrotizing hepatopancreatitis in Penaeus vannamei. J Invertebr Pathol 61:44-48

Hackett KL, Clark TB (1989) The ecology of spiroplasmas. In: Whitcomb RF, Tully JG (eds) The Mycoplasmas, Vol 5. Academic Press, New York, p 113-200

Hackett KJ, Lynn DE (1985) Cell-assisted growth of a fastidious spiroplasma. Science 230:825-826

Holthuis LB (1980) FAO species catalog, Vol 1. Shrimp and prawns of the world. FAO Fish Synop 125. FAO, Rome

Jones AL, Whitcomb RF, Williamson DL, Coan ME (1977) Comparative growth and primary isolation of spiroplasmas in media based on insect tissue culture formulations. Phytopathology 67:738-746

Lightner DV (1996) A handbook of shrimp pathology and diagnostic procedures for diseases of cultured penaeid shrimp. World Aquaculture Society, Baton Rouge, LA

Loy JK, Dewhirst FE, Weber W, Frelier PF, Garbar TL, Tasca SI, Templeton JW (1996) Molecular phylogeny in in situ detection of the etiologic agent of necrotizing hepatopancreatitis in shrimp. Appl Environ Microbiol 62:3439-3445

Maniatis T, Fritsch EF, Sambrook J (1982) Molecular cloning: a laboratory manual. Cold Spring Harbor Laboratory, Cold Spring Harbor, NY

Mohney LL, Lightner DV, Bell TA (1994) An epizootic of vibriosis in Ecuadorian pond-reared Penaeus vannamei Boone (Crustacea: Decapoda). J World Aquacult Soc 25:116-125

Nunan LM, Poulos B, Redman R, Le Groumellec M, Lightner DV (2003a) Molecular detection methods developed for a systemic rickettsia-like bacterium (RLB) in Penaeus monodon (Decapoda: Crustacea). Dis Aquat Org 53:15-23

Nunan LM, Noble B, LeGroumellec M, Lightner DV (2003b) Experimental infection of Penaeus vannamei by a rickett- 
sia-like bacterium (RLB) originating from $P$. monodon. Dis Aquat Org 54:43-48

Poulos BT, Mari J, Bonami JR, Redman R, Lightner DV (1994) Use of non-radioactively labeled DNA probes for the detection of a baculovirus from Penaeus monodon by in situ hybridization on fixed tissues. J Virol Methods 49:187-194

Pruder GD, Brown CL, Sweeney JN, Carr WH (1995) High health shrimp systems: seed supply-theory and practice. In: Browdy CL, Hopkins JS (eds) Swimming through trouble water. Proc Special Session on Shrimp Farming. World Aquaculture Society, Baton Rouge, LA, p 40-52

Razin S, Hasin M, Ne'eman Z, Rottem S (1973) Isolation, chemical composition and ultrastructure features of the cell membrane of the mycoplasma-like organism Spiroplasma citri. J Bacteriol 116:1421-1435

Saglio PM, L'Hospital, Lafleche D, Dupont G, Bove JM, Tully JG, Freundt EA (1973) Spiroplasma citri gen. and sp. nov.: a mycoplasma-like organism associated with Stubborn disease of citrus. Int J Syst Bacteriol 23:191-204

Trachtenberg S (1998) Mollicutes-wall-less bacteria with internal cytoskeletons. J Struct Biol 124:244-258

Tully JG, Whitcomb RF (1990) The genus Spiroplasma. In: Starr MP, Stolp H, Truper HG, Balows A, Schlegel HG (eds) The Prokaryotes. Springer-Verlag, New York, p 1960-1980

Tully JG, Whitcomb RF, Clark HF, Williamson DL (1977) Pathogenic mycoplasmas: cultivation and vertebrate pathogenicity of a new spiroplasma. Science 195:892-894

Tully JG, Whitcomb RF, Rose DL, Bove JM (1982) A new species from the rabbit tick (Haemaphysalis leporispalustris).

Editorial responsibility: Timothy Flegel,

Bangkok, Thailand
Int J Syst Bacteriol 32:92-100

Weisburg WG, Tully JG, Rose DL, Petzel JP and 8 others (1989) A phylogenetic analysis of the mycoplasmas: basis for their classification. J Bacteriol 171:6455-6467

Whitcomb RF, Tully JG, Rose DL, Stephens EB, Smith A, McCoy RE, Barile MF (1982) Wall-less prokaryotes from fall flowers in central United States and Maryland. Curr Microbiol 7:285-290

Williamson DL, Tully JG, Whitcomb RF (1979) Serological relationships of spiroplasmas as shown by combined deformation and metabolism inhibition tests. Int J Syst Bacteriol 29:345-351

Williamson DL, Tully JG, Whitcomb RF (1989) The genus Spiroplasma. In: Whitcomb RF, Tully JG (eds) The mycoplasmas, Vol 5. Academic Press, San Diego, CA, p 71-111

Williamson DL, Whitcomb RF, Tully JG, Gasparich GE and 9 others (1998) Revised group classification of the genus Spiroplasma. Int J Syst Bacteriol 48:1-12

Williamson DL, Sakaguchi B, Hackett KJ, Whitcomb RF and 6 others (1999) Spiroplasma poulsonii sp. nov., a new species associated with male-lethality in Drosophila willistoni, a neotropical species of fruit fly. Int J Syst Bacteriol 49:611-618

Wyban JA, Swingle JS, Sweeney JN, Pruder GD (1992) Development and commercial performance of high health shrimp using specific pathogen free (SPF) broodstock Penaeus vannamei. In: Wyban JA (ed) Proc Special Session on Shrimp Farming. World Aquaculture Society, Baton Rouge, LA, p 254-259

Submitted: February 25, 2004; Accepted: May 9, 2004 Proofs received from author(s): November 9, 2004 